\title{
Vital Pulpotomy and its Perspectives
}

\author{
Platonova $\mathrm{SA}^{1}$, Zhuralev $\mathrm{ON}^{2}$, Kartoshkin $\mathrm{AA}^{2}$, Petrikas $\mathrm{OA}^{3}$ and Petrikas $\mathrm{AZ}^{4 *}$ \\ ${ }^{1}$ Department of Therapeutic Stomatology, Tver Medical University, Russia \\ ${ }^{2}$ Tver Medical University, Russia \\ ${ }^{3}$ Department of Prosthetic dentistry, Tver State Medical University, Russia \\ ${ }^{4}$ Department Therapeutic Stomatology, Tver State Medical University, Russia
}

Submission: March 03, 2018; Published: September 07, 2018

"Corresponding author: Arnold Petrikas, Professor of Department of Therapeutic Stomatology, Tver State Medical University, 170100, Tver, Sovetskaya str, Russia, Email: petrikas2009@rambler.ru

Abstract

The article is devoted to the history of research and the development of materials being the protectors of the pulp used for vital amputation and direct pulp capping when it is accidentally exposed and also to the use of MTA in dentistry, including pediatric, as well as the prospect of the use of MTA in vital amputation of permanent teeth with the formed apex as a stage of preparation for prosthetics.

Keywords: Pulp; Apex; Vital amputation; Pulpotomy; Pulp protector; MTA; Primary teeth; Permanent teeth; Direct capping; In-direct capping

\section{Introduction}

Different materials for vital amputation and the reaction of the pulp are the subject of many studies [1-4]. Sometimes vital pulp therapy does not guarantee long-term success compared to endodontic treatment and the implications of various modifications of formocresol for pulpotomy of deciduous teeth are also not clear yet used since the 19 th century $[5,6]$. More than 30 years ago there already had been a huge choice of varnishes and cements for the preservation of pulp vitality [7]. Currently, vital pulp therapy is undergoing a remarkable progress thanks to the invention of new biomaterials in combination with the perfection of adhesive technology [8]. reviewed clinical studies on the pulp survival for 12 months after the intervention (19602016) with subsequent meta-analysis concluding any type of pulpotomy in deciduous teeth using the most efficient MTA and formocresol [9]. Overview of clinical studies by [10]. Showed the complexity of the interpretation of these studies and the creation of an ideal clinical conditions for the evaluation of the materials used [11]. There were practically no studies on pulpotomy teeth with carious lesions.

\section{The Types of Pulpotomy \\ Complete}

According to is the most appropriate for the permanent teeth with formed top [12].

\section{Partial}

Is described by Olsson et al. [13] 1 and 5minute lasting with formocresol $[14,15]$.

\section{The History of the Development}

Archaeological research showed that people of the Neolithic have been already familiar with the method of drilling and dental treatment. The remains of people with smooth holes of clearly artificial origin in teeth have been found on the territory of modern Pakistan. These graves are about 9 thousand years. It is assumed that the ancient physicians used substance similar to asphalt as the filling material. The papyri have brought to us a deep knowledge of the Egyptians about the healing properties of plants, which doctors of the time used in the manufacturing of filling materials and anti-inflammatory compounds for gingivitis, erosion and pulpitis treatment.

\section{The story of the protectors of the pulp}

First medicinal pulp capping was performed in 1756 by Philip Pfaff by applying gold leaf.

I. 1921: Calcium hydroxide was introduced by Hermann and for decades remained the "gold standard" to which, as a model other material have been compared.

II. 1969-70 gg: propose a mixture of antibiotics with corticosteroids for vital pulpotomy [16]. Describes the application "s Toverud 'paste" for pulpotomy [17]. Hannah $\mathrm{DR}$, Rowe AH. researched material N2 as an agent for pulpotomy.

III. 1975: Describes the use of a mixture of corticosteroids and antibiotics when performing a vital amputation of the lateral teeth [18]. 
IV. 1978: Explored the application of a combination of calcium hydroxide and antibiotic-glucocorticoid mixtures in the conservative treatment of pulp in carious posterior teeth [19].

V. 1986: Examined antibiotic-glucocorticoid compound for pulpotomy [20].

VI. 1987: J Melcer et al. [21-23] suggested carbon dioxide laser in the 1985-87 for pulp defects repairing.

VII. 1989: Recommended calcium hydroxide, formocresol, glutaraldehyde, ferric sulfate, zinc-eugenol cement, polycarboxylate cement for VA [24]. In the early 90s Torabinejad proposed MTA for the pulp treatment and many studies confirmed its advantages over calcium hydroxide.

VIII. 1993: MTA is presented by dentistry market.

IX. 1994: Offered tricalcium phosphate in combination with a small amount of calcium hydroxide for pulpotomy [25].

X. 1995: Calcium phosphate cement is biocompatible and mechanically stable due to its ability to transform into a hydroxyapatite which is the most thermodynamically stable agent with good biocompatibility and $\mathrm{pH}$ 7.0. Yoshimine $\mathrm{Y}$ et al. [26] demonstrated that tetracalcium phosphate, unlike calcium hydroxide, stimulating the formation of the dentinal bridge without the risk of pulp necrosis and inflammation.

XI. 1996: Proposed a hydroxyapatite and beta-tricalcium phosphate for pulpotomy, guaranteeing the formation of dentin barrier [27].

XII. 1997: Consider ferric sulfate and modification of formocresol to be acceptable for pulpotomy of deciduous teeth reaffirming at the same time some cases of internal resorption during their application [28]. Note the same efficiency of formocresol and zinc-eugenol cement in pulpotomy In vivo, and that the ferric sulphate had no higher efficacy compared to these agents [29].

XIII. 2000: Ferric sulfate is recommended for pulpotomy of deciduous teeth [30]. Proposed the paste on the basis of the iodoform for pulpotomy of primary and permanent teeth in children [31].

XIV. 2001: Recommend MTA for pulpotomy in deciduous teeth [32].

XV. 2002: In vivo studies by [33]. Who investigated the direct capping of the inflamed pulp with calcium hydroxide showed the subsequent formation of the dentinal bridge.

XVI. 2003: Recommended ferric sulfate because of its low toxicity in comparison with formocresol for pulpotomy in primary molars [34]. Histological examination by [35]. Showed the superiority of MTA over other agents for pulpotomy in maintaining the health and integrity of the pulp.

XVII. 2004: Research by [36]. Showed the superiority of MTA over formocresol in pulpotomy of deciduous teeth.

XVIII. 2005: In his review study notes that among all the possible agents for pulpotomy of deciduous teeth formocresol is the most predictable and effective [37].

XIX. 2006: Suggest MTA for pulpotomy of primary teeth [38].

XX. 2008: Determined that the efficiency of electrocoagulation and formocresol is the same when performing pulpotomy of primary teeth in children 5-10 years. Offer the enamel matrix derivative as an alternative to formocresol for pulpotomy of deciduous teeth $[39,40]$.

XXI. 2009: Recommended Portland cement as a cheaper alternative to MTA in pulpotomy of primary teeth. Propose the hydroxyapatite as the pulpotomy agent $[41,42]$.

XXII. 2011: Recommended ferric sulfate pulpotomy for carious deciduous teeth [43].

XXIII. 2012: Assess zinc eugenol as an acceptable agent for pulpotomy $[44,45]$. Noted that the MTA, with all its effectiveness on the formation of dentinal bridges can thereby complicate future endodontic treatment [46]. Consider the bioceramic as an optimal agent for pulpotomy [47]. Made an attempt to mix formocresol and MTA. Propose the technique of minipulpotomy $[48,49]$.

XXIV. 2013: Offer collagen and Pulpotec for pulpotomy. In addition to the use of MTA and CEM, the authors continue to assess zinc eugenol satisfactorily as pulpotomy agent in children [50,51]. Studied formocresol as a standard offering sodium hypochlorite as an agent for pulpotomy along with the MTA [52,53].

XXV. 2014: Offer preparations of fibrin as alternative to MTA for pulpotomy in permanent teeth with incomplete apexogenesis [54].

XXVI. 2015: Propose the use of stem cells for efficient healing of the pulp and the formation of tertiary dentin during pulpotomy [55]. In vivo have confirmed the biocompatibility and effectiveness of the bioceramic iRoot BP Plus (Innovative Bioceramix Inc, Vancouver, Canada) for pulpotomy [56]. Portland cement is still used in pulpotomy of primary teeth with the addition of iodoform and zirconium oxide with the appropriate reaction of the pulp within 24 months after the intervention [57].

XXVII. 2017: Offered a herbal preparation with Turmeric powder for pulpotomy of deciduous teeth [58]. Proposed propolis in the form of biodegradable films based on chitosan [59]. 


\section{Physical Methods Pulpotomy}

Showed the same efficiency of the laser and Biodentical MTA for pulpotomy in primary teeth [60]. Noted the great efficiency of the laser pulpotomy compared to ferric sulfate and electrocoagulation in clinical studies of children 4-10 years according to clinical and radiological parameters [61]. Consider the laser and electrocoagulation acceptable alternative to pharmacotherapeutic pulpotomy agents [62]. Determined in vivo high efficiency of the KaVo Gentle Ray Diode Laser compared to formocresol and ferric sulfate consider electrocoagulation being efficient enough in the clinic of pediatric dentistry [63].

\section{MTA in Pediatric Dentistry}

Believe that the MTA, in particular white, soon will completely replace the "gold standard" formocresol in pulpotomy of deciduous teeth, outperforming its clinical and radiographic efficiency according to research by as well as to in vivo studies believe that the MTA provides normal apexogenesis during partial pulpotomy [64 -70]. In clinical trials for postoperative pain in primary teeth of the 6-10 years children after pulpotomy of carious molars determined that MTA and CEM were equally effective [71]. Efficacy of MTA and CEM pulpotomy in primary teeth is affirmed by [72]. The effectiveness of pulpotomy with MTA for primary teeth is demonstrated by MTA prevents premature removal of deciduous teeth [73-75]. Note the almost identical efficiency of Biodentin, white MTA and Tempopro for the treatment of carious deciduous teeth [76]. Confirmed the superiority of MTA as a pulpotomy agent for primary teeth over formocresol, Portland cement and enamel matrix derivative and confirmed that the MTA and Bidention are reliable materials for the pulpotomy of primary teeth [77-79]. Showed the same efficiency of MTA, calcium hydroxide and enriched fibrin for pulpotomy of molars with the formed apex with irreversible pulpitis $[80,81]$.

Noted greater efficiency and the potential for the formation of reparative dentin of Biodentin compared to calcium hydroxide (Pulpdent) when conducting pulpotomy in the 5-10 years children identified greater efficiency of MTA in comparison with formocresol during clinical studies of the primary teeth in the 5-8 years children [82-84]. Emphasize equally high efficiency of various types of MTA - RetroMTA, OrthoMTA and ProRoot MTA for pulpotomy in deciduous teeth [85]. consider it appropriate to use MTA and Portland cement for pulpotomy in deciduous teeth, affirming their reparative and bioinductive properties by the presence of dentin matrix protein DMP -in their review of the studies revealed a higher and long-term effectiveness of MTA in primary teeth pulpotomy in contrast to the ferric sulfate $[86,87]$. Recommend the treatment with 5\% sodium hypochlorite to ensure maximum effectiveness of calcium in primary teeth pulpotomy [88].

\section{Pulpotomy in Permanent Teeth}

consider Biodentin and MTA to be effective for the treatment of traumatized permanent incisors [89]. believe that pulpotomy with MTA is a reliable alternative to endodontic treatment of permanent teeth in children [90]. Confirmed similar efficacy of CEM and MTA in pulpotomy of permanent first molars with incomplete apexogenesis [91]. noted the effectiveness of MTA in pulpotomy of permanent molars with carious lesions [92]. Recommend MTA pulpotomy for permanent teeth with incomplete apexogenesis [13].

\section{The Advantages of Modern Materials}

note the absence of toxic and mutagenic effect in C|EM compared to formocresol and ferric sulfate [93]. observed normal apexogenesis in pulpotomy of the 12 years girl second lower molar. confirm the minimum of toxic effect on the fibroblasts of the periodontium of white and grey MTA $[94,95]$. MTA is superior to calcium hydroxide on efficiency Northwest Practice-based Research Collaborative in Evidence-based According to in vivo studies by MTA and CEM are superior to calcium hydroxide for a favorable response and further healing of the pulp [96,97]. MTA has a lower cytotoxicity compared to calcium hydroxide Histological examination by demonstrated the efficacy of tricalcium phosphate, MTA and Portland cement in contrast to formocresol and ferric sulphate $[98,99]$.

\section{Disadvantages of Modern Materials}

In their review of electronic database studies have evaluated the MTA potential for the formation of a protective barrier of hard tissues compared to calcium hydroxide as questionable [100]. In addition, the analysis of electronic databases of studies from 1950 to 2013 by never found out the preferred tactics in the treatment of teeth with deep carious lesions, endodontic treatment or pulpotomy [101]. Found out a weak inhibitory effect on cariogenic bacteria from MTA in primary teeth pulpotomy [102].

\section{MTA Mechanism of Action}

MTA is calcium oxide in the form of tri- and di- silicate with tricalcium aluminate prior to setting. The first product of the reaction between MTA and water is calcium hydroxide, which provides its biocompatibility [103]. Thus, MTA has all the properties of calcium hydroxide, and also provides a better connection to the dentin. In addition, the MTA reacts with fluids containing phosphates resulting in a precipitate in the form of hydroxyapatite [104]. Several authors have attributed high solubility in water high duration setting material gray MTA containing iron, can stain the tooth tissue to the shortcomings of MTA [105-107]. MTA is a universal material in the clinic of pediatric dentistry, ensuring the preservation of pulp vitality and the root pulp in particular and, therefore, a complete root formation of immature permanent teeth. MTA appears to be an apical barrier during the periodontitis treatment of immature teeth providing normal apex development [108]. Considers the possibility of completing the treatment of the tooth in one visit to be an advantage of MTA over calcium hydroxide, but some MTA types may cause clinical crown discoloration (Table 1). 
Table 1:

\begin{tabular}{|c|c|c|c|}
\hline Overview & Witherspoon DE [109] & MTA & $\begin{array}{l}\text { MTA unlike calcium hydroxide has better } \\
\text { integrity and a greater ability to stimulate the } \\
\text { formation of perfect reparative dentin. }\end{array}$ \\
\hline Physical & $\begin{array}{l}\text { Eid AA, Komabayashi T, Watanabe } \\
\text { E, Shiraishi T, Watanabe I. } \\
\text { Interaction } 2012 \text { [110] }\end{array}$ & MTA and the GIC & $\begin{array}{l}\text { GIC can be directly superimposed directly on } \\
\text { the freshly mixed MTA without impairing the } \\
\text { characteristics of these materials. }\end{array}$ \\
\hline $\begin{array}{l}\text { Physics (research } \\
\text { tensile strength) }\end{array}$ & $\begin{array}{l}\text { Savadi Oskoee S, Bahari M, Kimyai } \\
\text { S, Motahhari P, Eghbal MJ, Asgary } \\
\text { S (2014) }\end{array}$ & $\begin{array}{l}\text { White MTA and CEM with } \\
\text { different composite and } \\
\text { adhesive systems }\end{array}$ & $\begin{array}{l}\text { White MTA and CEM do not differ from each } \\
\text { other in less strong adhesion to the composite } \\
\text { in contrast to the composite glassionomeric } \\
\text { cement }\end{array}$ \\
\hline In vitro (Neutrophils) & $\begin{array}{l}\text { Cavalcanti BN, Rode Sde M, França } \\
\text { CM, Marques MM [111] }\end{array}$ & MTA & $\begin{array}{l}\text { MTA unlike calcium hydroxide causes increased } \\
\text { production of interleukin } 1-\beta .\end{array}$ \\
\hline In vitro (pulp cells) & $\begin{array}{l}\text { Paranjpe A, Smoot T, Zhang H, } \\
\text { Johnson JD [112] }\end{array}$ & Gray MTA & $\begin{array}{l}\text { Pulp cells are converted into odontoblasts with } \\
\text { increased secretion of vascular endothelial } \\
\text { growth factor in contact with gray MTA. }\end{array}$ \\
\hline Clinical and histological & $\begin{array}{c}\text { Banava S, Fazlyab M, Heshmat H, } \\
\text { Mojtahedzadeh F, Motahhary P } \\
\text { (2015) }\end{array}$ & $\begin{array}{l}\text { Dycal, ProRoot MTA, ProRoot } \\
\text { MTA, Multi-Cal }\end{array}$ & $\begin{array}{c}\text { Pulpotomy in one visit with MTA as direct } \\
\text { pulp protector is just as effective as a similar } \\
\text { procedure in two visits using calcium } \\
\text { hydroxide. }\end{array}$ \\
\hline Clinical & $\begin{array}{l}\text { Malekafzali B, Shekarchi F, Asgary } \\
\qquad \text { S (2011) }\end{array}$ & MTA and CEM & $\begin{array}{l}\text { Both materials are effective in primary molars } \\
\text { pulpotomy }\end{array}$ \\
\hline Clinical & Simon S, et al. (2012) & MTA & $\begin{array}{l}\text { pulpotomy with MTA is successful in patients } \\
\text { from } 7 \text { to } 54 \text { years in premolars and molars } \\
\text { with no symptoms of irreversible pulpitis. }\end{array}$ \\
\hline \multirow[t]{2}{*}{ Clinical } & $\begin{array}{c}\text { Hilton TJ, Ferracane JL, Mancl L } \\
\text { [113] }\end{array}$ & & \\
\hline & MTA & $\begin{array}{l}\text { MTA is superior to calcium } \\
\text { hydroxide as a direct pulp } \\
\text { protector }\end{array}$ & \\
\hline Clinical & Asgary S, Eghbal MJ (2013) & MTA and CEM & $\begin{array}{l}\text { Both materials ensure success in the treatment } \\
\text { of molars with irreversible pulpitis. }\end{array}$ \\
\hline Clinical & Azimi S et al. [114] & iRoot BP or MTA & $\begin{array}{l}\text { no necrosis of the pulp, dentin bridge is formed } \\
\text { in } 100 \%\end{array}$ \\
\hline Clinical & $\begin{array}{l}\text { Barngkgei IH, Halboub E, Alboni } \\
\text { RS [115] }\end{array}$ & ProRoot MTA & $\begin{array}{l}\text { pulpotomy with MTA - reliable alternative to } \\
\text { endodontic treatment. }\end{array}$ \\
\hline Clinical & $\begin{array}{l}\text { Fallahinejad Ghajari M, Asgharian } \\
\text { Jeddi T, Iri S, Asgary S [116] }\end{array}$ & MTA ProRoot and CEM & $\begin{array}{l}\text { Both materials are equally effective as direct } \\
\text { pulp protectors in the primary teeth treatment. }\end{array}$ \\
\hline
\end{tabular}

\section{Recommendations for the MTA Use}

Studies showed that the compound of composite GIC and white MTA was stable regardless the presence of the etching material [116-117]. The authors recommended isolating liner of composite GIC with its further etching along with dentin for pulp capping and restoration of bifurcation using MTA. The review of studies indicates the possibility of the future use of MTA not only medicinally, but also in the preparation of the permanent teeth for prosthetics [118-119]. Even Pierre Foshar in his works, recognized the significant loss of hard tissues during endodontic treatment, leading to additional complicated and sometimes risky prosthetic procedures.

\section{References}

1. Bartsch J, Bartholomäus S, Bartholomäus K, Beetke E, Bienengräber V (1985) Pulp reaction of human deciduous teeth to different materials after vital and mortal amputation. Zahn Mund Kieferheilkd Zentralbl 73(3): 275-282.
2. Shima S (1980) Clinico-pathological studies of influence of zinc oxideeugenol sealers for the wound of human pulp after vital amputation in middle portion of the root canal (author's transl). Shikwa Gakuho 80(9): 1203-1264.

3. Sotillo Gómez M (1970) Acid cements and pulp protectors. Acta Odontol Venez 8(2): 155-167.

4. Watanabe I (1969) Clinicopathological study on vital pulp amputation in the aged. Shikwa Gakuho 69(8): 1-43.

5. Ward J (2008) Vital pulp therapy in cariously exposed permanent teeth and its limitations. Aust Endod J 28(1): 29-37.

6. Nunn JH, Smeaton I, Gilroy J (1996) The development of formocresol as a medicament for primary molar pulpotomy procedures. ASDC J Dent Child 63(1): 51-53.

7. Vannier R (1984) Pulp protectors and the deep regions of the cavity. Rev Stomatol Chir Maxillofac 85(3): 235-9.

8. Gabrielli F, Dinelli W, Fontana UF, Rolfsen RL (1972) Pulp protectorsconcepts and current status. Rev Bras Odontol 29(177): 267-274.

9. Cao Y, Bogen G, Lim J, Shon WJ, Kang MK (2016) Bioceramic Materials 
and the Changing Concepts in Vital Pulp Therapy. J Calif Dent Assoc 44(5): 278-290.

10. Coll JA, Seale NS, Vargas K, Marghalani AA, Al Shamali S, et al. (2017) Primary Tooth Vital Pulp Therapy: A Systematic Review and Metaanalysis. Pediatr Dent 39(1): 16-123.

11. Miyashita H, Worthington HV, Qualtrough A, Plasschaert A (2016) WITHDRAWN: Pulp management for caries in adults: maintaining pulp vitality. Cochrane Database Syst Rev 11: CD004484.

12. Alqaderi H, Lee CT, Borzangy S, Pagonis TC (2016) Coronal pulpotomy for cariously exposed permanent posterior teeth with closed apices: A systematic review and meta-analysis. J Dent 44: 1-7.

13. El-Meligy OA, Avery DR (2006) Comparison of mineral trioxide aggregate and calcium hydroxide as pulpotomy agents in young permanent teeth (apexogenesis). Pediatr Dent 28(5): 399-404.

14. Swift EJ Jr, Trope M (1999) Treatment options for the exposed vital pulp. Pract Periodontics Aesthet Dent 11(6): 735-739.

15. Kurji ZA, Sigal MJ, Andrews P, Titley K (2011) A retrospective study of a modified 1-minute formocresol pulpotomy technique part 2: effect on exfoliation times and successors. Pediatr Dent 33(2): 139-143.

16. Virolainen K, Nyström M, Elomaa M (1969-1970) Vital pulpotomy of deciduous teeth using chemotherapeutic-corticoid combination. Arsb Odontol Samf Finl 62-69.

17. Sveen OB (1970) Pulpotomy of primary molar teeth using Toverud's paste. Scand J Dent Res 78(2): 149-162.

18. Barker BC (1975) Conservative treatment of cariously exposed vital pulps in posterior teeth with a glucocorticosteroid-antibiotic compound. J Br Endod Soc 8(1): 5-15.

19. Holland R, de Souza V, de Mello W, Nery MJ, Pannain R, et al. (1978) Healing process of dental pulp after pulpotomy or curettage and calcium hydroxide protection. Effect of corticosteroid dressing. Rev Fac Odontol Aracatuba 7(2): 153-161.

20. Herrero Moraes S, de Aragao EM, Heck A (1986) Clinical effectiveness of a corticosteroid-antibiotic mixture used in pulpotomy and pulpectomy. Dens (Curitiba) 1(1): 14-8.

21. Melcer J, Chaumette MT, Melcer F (1987) Dental pulp exposed to the $\mathrm{CO}_{2}$ laser beam. Lasers Surg Med 7(4): 347-352.

22. Melcer J (1986) Latest treatment in dentistry by means of the $\mathrm{CO}_{2}$ laser beam. Lasers Surg Med 6(4): 396-398.

23. Melcer J, Chaumette MT, Melcer F (1985) Experimental research on the preparation of dentin-pulp tissue of teeth exposed to $\mathrm{CO} 2$ laser beams in dogs and macaques (Macaca/mulatta and Macaca fascicularis). C R Seances Soc Biol Fil 179(5): 577-585.

24. Alacam A (1989) Pulpal tissue changes following pulpotomies with formocresol, glutaraldehyde-calcium hydroxide, glutaraldehyde-zinc oxide eugenol pastes in primary teeth. J Pedod 13(2): 123-132.

25. Yoshiba K, Yoshiba N, Iwaku M (1994) Histological observations of hard tissue barrier formation in amputated dental pulp capped with alpha-tricalcium phosphate containing calcium hydroxide. Endod Dent Traumatol 10(3): 113-120.

26. Yoshimine Y, Maeda K (1995) Histologic evaluation of tetracalcium phosphate-based cement as a direct pulp-capping agent. Oral Surg Oral Med Oral Pathol Oral Radiol Endod 79(3): 351-358.

27. Higashi $\mathrm{T}$, Okamoto $\mathrm{H}$ (1996) Influence of particle size of calcium phosphate ceramics as a capping agent on the formation of a hard tissue barrier in amputated dental pulp. J Endod 22(6): 281-283.

28. Fuks AB, Holan G, Davis JM, Eidelman E (1997) Ferric sulfate Versus dilute formocresol in pulpotomized primary molars: long-term follow up. Pediatr Dent 19(5): 327-330.
29. Cotes O, Boj JR, Canalda C, Carreras M (1997) Pulpal tissue reaction to formocresol vs ferric sulfate in pulpotomized rat teeth. J Clin Pediatr Dent 21(3): 247-253.

30. Ibricevic $\mathrm{H}$, al-Jame Q (2000) Ferric sulfate as pulpotomy agent in primary teeth: twenty-month clinical follow-up. J Clin Pediatr Dent 24(4): 269-272.

31. Ranly DM, Garcia-Godoy F (2000) Current and potential pulp therapies for primary and young permanent teeth. J Dent 28(3): 153161.

32. Eidelman E, Holan G, Fuks AB (2001) Mineral trioxide aggregate vs. formocresol in pulpotomized primary molars: a preliminary report. Pediatr Dent 23(1): 15-8.

33. Trope M, Mc Dougal R, Levin L, May KN Jr, Swift EJ Jr (2002) Capping the inflamed pulp under different clinical conditions. J Esthet Restor Dent 14(6): 349-357.

34. Ibricevic H, Al-Jame Q (2003) Ferric sulphate and formocresol in pulpotomy of primary molars: long term follow-up study. Eur J Paediatr Dent 4(1): 28-32.

35. Dominguez MS, Witherspoon DE, Gutmann JL, Opperman LA (2003) Histological and scanning electron microscopy assessment of various vital pulp-therapy materials. J Endod 29(5): 324-333.

36. Agamy HA, Bakry NS, Mounir MM, Avery DR (2004) Comparison of mineral trioxide aggregate and formocresol as pulp-capping agents in pulpotomized primary teeth. Pediatr Dent 26(4): 302-309.

37. Castro A (2005) Current concepts in vital pulpotomies in primary teeth. J Mich Dent Assoc 87(1): 26-8.

38. Percinoto C, de Castro AM, Pinto LM (2006) Clinical and radiographic evaluation of pulpotomies employing calcium hydroxide and trioxide mineral aggregate. Gen Dent 54(4): 258-261.

39. Bahrololoomi Z, Moeintaghavi A, Emtiazi M, Hosseini G (2008) Clinical and radiographic comparison of primary molars after formocresol and electrosurgical pulpotomy: a randomized clinical trial. Indian J Dent Res 19(3): 219-223.

40. Sabbarini J, Mohamed A, Wahba N, El-Meligy O, Dean J (2008) Comparison of enamel matrix derivative versus formocresol as pulpotomy agents in the primary dentition. J Endod 34(3): 284-287.

41. Sakai VT, Moretti AB, Oliveira TM, Fornetti AP, Santos CF, et al. (2009) Pulpotomy of human primary molars with MTA and Portland cement: a randomized controlled trial. Br Dent J 207(3): 128-9.

42. Adlakha VK, Chandna P, Joshi J, Thomas A, Singh N (2009) A comparative evaluation of hydroxyapatite crystals and glutaraldehyde as agents for pulpotomy in deciduous molars. Int J Clin Pediatr Dent 2(1): 13-22

43. Huth KC, Hajek-Al-Khatar N, Wolf P, Ilie N, Hickel R, et al. (2012) Longterm effectiveness of four pulpotomy techniques: 3-year randomised controlled trial. Clin Oral Investig 16(4): 1243-1250.

44. Ghoddusi J, Shahrami F, Alizadeh M, Kianoush K, Forghani M (2012) Clinical and radiographic evaluation of vital pulp therapy in open apex teeth with MTA and ZOE. N Y State Dent J 78(3): 34-38.

45. Erdem AP, Guven Y, Balli B, Ilhan B, Sepet E, et al. (2011) Success rates of mineral trioxide aggregate, ferric sulfate, and formocresol pulpotomies: a 24-month study. Pediatr Dent 33(2): 165-170.

46. Srinivasan D, Jayanthi M (2011) Comparative evaluation of formocresol and mineral trioxide aggregate as pulpotomy agents in deciduous teeth. Indian J Dent Res 22(3): 385-390.

47. Koch KA, Brave DG (2012) Bioceramics, Part 2: The clinician's viewpoint. Dent Today 31(2): 122-125.

48. Frenkel G, Kaufman A, Ashkenazi M (2012) Clinical and radiographic outcomes of pulpotomized primary molars treated with white or 
gray mineral trioxide aggregate and ferric sulfate-long-term followup. J Clin Pediatr Dent 37(2): 137-141.

49. Asgary S, Ahmadyar M (2012) Can miniature pulpotomy procedure improve treatment outcomes of direct pulp capping? Med Hypotheses 78(2): 283-285

50. Kakarla P, Avula JS, Mellela GM, Bandi S, Anche S (2013) Dental pulp response to collagen and pulpotec cement as pulpotomy agents in primary dentition: A histological study. J Conserv Dent 16(5): 434438.

51. Harandi A, Forghani M, Ghoddusi J (2013) Vital pulp therapy with three different pulpotomy agents in immature molars: a case report. Iran Endod J 8(3): 145-148.

52. Fernández CC, Martínez SS, Jimeno FG, Lorente Rodríguez AI, Mercadé M (2013) Clinical and radiographic outcomes of the use of four dressing materials in Frankl Z. Treatment of vital exposed pulps in molars with $\mathrm{N}_{2}$ normal (I). Quintessence Int Dent Dig 9(4): 17-23.

53. Fernández CC1, Martínez SS, Jimeno FG, Lorente Rodríguez AI, Mercadé M (2013) clinical and radiographic outcomes of the use of four dressing materials in pulpotomized primary molars: a randomized clinical trial with 2-year follow-up. Int J Paediatr Dent 23(6): 400-407.

54. Keswani D, Pandey RK, Ansari A, Gupta S (2014) Comparative evaluation of platelet-rich fibrin and mineral trioxide aggregate as pulpotomy agents in permanent teeth with incomplete root development: a randomized controlled trial. J Endod 40(5): 599-605.

55. Surendran S, Sivamurthy G (2015) Current Applications and Future Prospects of Stem Cells in Dentistry. Dent Update 42(6): 556-8, 560561.

56. Liu S, Wang S, Dong Y (2015) Evaluation of a bioceramic as a pulp capping agent in vitro and in vivo. J Endod41(5): 652-657.

57. M, Rios D, Machado MA, Oliveira T (2015) Pulp tissue response to Portland cement associated with different radio pacifying agents on pulpotomy of human primary molars. J Microsc 260(3): 281-286.

58. Purohit RN, Bhatt M, Purohit K, Acharya J, Kumar R, et al. (2017) Clinical and Radiological Evaluation of Turmeric Powder as a Pulpotomy Medicament in Primary Teeth: An in vivo Study. Int J Clin Pediatr Dent 10(1): 37-40.

59. Balata GF, Abdelhady MI, Mahmoud GM, Matar MA, Abd El-Latif AN (2018) Formulation of Saudi propolis into biodegradable chitosan chips for vital pulpotomy. Curr Drug Deliv 15(1): 97-100.

60. Niranjani K, Prasad MG, Vasa AA, Divya G, Thakur MS, et al. (2015) Clinical Evaluation of Success of Primary Teeth Pulpotomy Using Mineral Trioxide Aggregate (®), Laser and Biodentine (TM)- an In Vivo Study. J Clin Diagn Res 9(4): ZC35-ZC37.

61. Gupta G, Rana V, Srivastava N, Chandna P (2015) Laser PulpotomyAn Effective Alternative to Conventional Techniques: A 12 Months Clinicoradiographic Study. Int J Clin Pediatr Dent 8(1): 18-21.

62. Yadav P, Indushekar K, Saraf B, Sheoran N, Sardana D (2014) Comparative evaluation of Ferric Sulfate, Electrosurgical and Diode Laser on human primary molars pulpotomy: an in-vivo study. Laser Ther 23(1): 41-47.

63. Cannon M, Wagner C, Thobaben JZ, Jurado R, Solt D (2011) Early response of mechanically exposed dental pulps of swine to antibacterial-hemostatic agents or diode laser irradiation. J Clin Pediatr Dent 35(3): 271-276.

64. Olatosi 00, Sote EO, Orenuga 00 (2015) Effect of mineral trioxide aggregate and formocresol pulpotomy on vital primary teeth: a clinical and radiographic study. Niger J Clin Pract 18(2): 292-296.

65. Sushynski JM, Zealand CM, Botero TM, Boynton JR, Majewski RF, et al. (2012) Comparison of gray mineral trioxide aggregate and diluted formocresol in pulpotomized primary molars: a 6- to 24-month observation. Pediatr Dent 34(5): 120-128.

66. Zealand CM, Briskie DM, Botero TM, Boynton JR, Hu JC (2010) Comparing gray mineral trioxide aggregate and diluted formocresol in pulpotomized human primary molars. Pediatr Dent 32(5): 393 399.

67. Cuadros-Fernández C, Lorente Rodríguez AI, Sáez-Martínez S, de Menezes JV, Takamori ER, et al. (2009) In vitro toxicity of MTA compared with other primary teeth pulpotomy agents. J Clin Pediatr Dent 33(3): 217-221.

68. Noorollahian H (2008) Comparison of mineral trioxide aggregate and formocresol as pulp medicaments for pulpotomies in primary molars. Br Dent J 204(11): E20.

69. Karami B, Khayat A, Moazami F, Pardis S, Abbott P (2009) Histological evaluation of the effect of three medicaments; trichloracetic acid, formocresol and mineral trioxide aggregate on pulpotomised teeth of dogs. Aust Endod J 35(1): 18-28.

70. Caprioglio A, Conti V, Caprioglio C, Caprioglio D (2014) A longterm retrospective clinical study on MTA pulpotomies in immature permanent incisors with complicated crown fractures. Eur J Paediatr Dent 15(1): 29-34.

71. Shafie L, Barghi H, Parirokh M, Ebrahimnejad H, Nakhae N, et al. (2014) Postoperative Pain following Pulpotomy of Primary Molars with Two Biomaterials: A Randomized Split Mouth Clinical Trial. Iran Endod J 12(1): 10-14.

72. Malekafzali B, Shekarchi F, Asgary S (2011) Treatment outcomes of pulpotomy in primary molars using two endodontic biomaterials. A 2-year randomised clinical trial. Eur J Paediatr Dent 12(3): 189-193.

73. Abou Chedid JC, Mchayleh N, Khalil I, Melki B, Hardan LS (2015) An 18month evaluation of MM-MTA pulpotomy on primary decayed molars. Odontostomatol Trop 38(152): 17-24.

74. Moretti AB, Sakai VT, Oliveira TM, Fornetti AP, Santos CF, et al. (2008) The effectiveness of mineral trioxide aggregate, calcium hydroxide and formocresol for pulpotomies in primary teeth. Int Endod J 41(7): 547-555.

75. Airen P, Shigli A, Airen B (2012) Comparative evaluation of formocresol and mineral trioxide aggregate in pulpotomized primary molars--2 year follow up. J Clin Pediatr Dent 37(2): 143-147.

76. Rajasekharan S, Martens LC, Vandenbulcke J, Jacquet W, Bottenberg P, et al. (2017) Efficacy of three different pulpotomy agents in primary molars: a randomized control trial. Int Endod J 50(3): 215-228.

77. Yildirim C, Basak F, Akgun OM, Polat GG, Altun C (2016) Clinical and Radiographic Evaluation of the Effectiveness of Formocresol, Mineral Trioxide Aggregate, Portland Cement, and Enamel Matrix Derivative in Primary Teeth Pulpotomies: A Two-Year Follow-Up. J Clin Pediatr Dent 40(1): 14-20.

78. Togaru H, Muppa R, Srinivas N, Naveen K, Reddy VK, et al. (2016) Clinical and Radiographic Evaluation of Success of Two commercially Available Pulpotomy Agents in Primary Teeth: An in vivo Study. J Contemp Dent Pract 17(7): 557-563.

79. Kumar V, Juneja R, Duhan J, Sangwan P, Tewari S (2016) Comparative evaluation of platelet-rich fibrin, mineral trioxide aggregate, and calcium hydroxide as pulpotomy agents in permanent molars with irreversible pulpitis: A randomized controlled trial. Contemp Clin Dent 7(4): 512-518.

80. García-Binimelis J, About I, Mercadé M (2016) Short-term treatment outcome of pulpotomies in primary molars using mineral trioxide aggregate and Biodentine: a randomized clinical trial. Clin Oral Investig 20(7): 1639-1645.

81. Gonzalez-Lara A, Ruiz-Rodriguez MS, Pierdant-Perez M, GarrochoRangel JA, Pozos-Guillen AJ (2016) Zinc Oxide-Eugenol Pulpotomy 
in Primary Teeth: A 24-Month Follow-up. J Clin Pediatr Dent 40(2): 107-112.

82. Grewal N, Salhan R, Kaur N, Patel HB (2016) Comparative evaluation of calcium silicate-based dentin substitute (Biodentine (®)) and calcium hydroxide (pulpdent) in the formation of reactive dentin bridge in regenerative pulpotomy of vital primary teeth: Triple blind, randomized clinical trial. Contemp Clin Dent 7(4): 457-463.

83. Liu H, Zhou Q Qin M (2011) Mineral trioxide aggregate versus calcium hydroxide for pulpotomy in primary molars. Chin J Dent Res 14(2): 121-125

84. Godhi B, Sood PB, Sharma A (2011) Effects of mineral trioxide aggregate and formocresol on vital pulp after pulpotomy of primary molars: An in vivo study. Contemp Clin Dent 2(4): 296-301.

85. Kang CM, Kim SH, Shin Y, Lee HS, Lee JH, et al. (2015) A randomized controlled trial of ProRoot MTA, OrthoMTA and RetroMTA for pulpotomy in primary molars. Oral Dis 21(6): 785-791.

86. Lourenço Neto N, Marques NC, Fernandes AP, Rodini CO, Sakai VT, et al. (2016) Immunolocalization of dentin matrix protein-1 in human primary teeth treated with different pulp capping materials. J Biomed Mater Res B Appl Biomater 104(1): 165-169.

87. Asgary S, Shirvani A, Fazlyab M (2014) MTA and ferric sulfate in pulpotomy outcomes of primary molars: a systematic review and meta-analysis. J Clin Pediatr Dent 39(1): 1-8.

88. Akcay M, Sari S (2014) The effect of sodium hypochlorite application on the success of calcium hydroxide and mineral trioxide aggregate pulpotomies in primary teeth. Pediatr Dent 36(4): 316-321.

89. Martens L, Rajasekharan S, Cauwels R (2015) Pulp management after traumatic injuries with a tricalcium silicate-based cement (Biodentine $^{\mathrm{TM}}$ ): a report of two cases, up to 48 months follow-up. Eur Arch Paediatr Dent 16(6): 491-496.

90. Alqaderi HE, Al-Mutawa SA, Qudeimat MA (2014) MTA pulpotomy as an alternative to root canal treatment in children's permanent teeth in a dental public health setting. J Dent 42(11): 1390-1395.

91. Nosrat A, Seifi A, Asgary S (2013) Pulpotomy in caries-exposed immature permanent molars using calcium-enriched mixture cement or mineral trioxide aggregate: a randomized clinical trial. Int J Paediatr Dent 23(1): 56-63.

92. Qudeimat MA, Barrieshi-Nusair KM, Owais AI (2007) Calcium hydroxide vs mineral trioxide aggregates for partial pulpotomy of permanent molars with deep caries. Eur Arch Paediatr Dent 8(2): 99-104.

93. Samiei M, Asgary S, Farajzadeh M, Bargahi N, Abdolrahimi M, et al (2015) Investigating the mutagenic effects of three commonly used pulpotomy agents using the ames test. Adv Pharm Bull 5(1): 121-125.

94. Nosrat A, Asgary S (2010) Apexogenesis of a symptomatic molar with calcium enriched mixture. Int Endod J 43(10): 940-944.

95. Al-Haj Ali SN, Al-Jundi SH, Ditto DJ (2014) In vitro toxicity of grey MTA in comparison to white MTA on human periodontal ligament fibroblasts. Eur Arch Paediatr Dent 15(6): 429-333.

96. Hilton TJ, Ferracane JL, Mancl L (2013) Northwest Practice-based Research Collaborative in Evidence-based Dentistry (NWP). Comparison of $\mathrm{CaOH}$ with MTA for direct pulp capping: a PBRN randomized clinical trial. J Dent Res 92(7 Suppl):16S-22S.

97. Tabarsi B, Parirokh M, Eghbal MJ, Haghdoost AA, Torabzadeh $\mathrm{H}$ Asgary S A comparative study of dental pulp response to several pulpotomy agents. Int Endod J 43(7): 565-571.

98. de Souza Costa CA, Duarte PT, de Souza PP, Giro EM, Hebling J (2008) Cytotoxic effects and pulpal response caused by a mineral trioxide aggregate formulation and calcium hydroxide. Am J Dent 21(4): 255261.
99. Shayegan A, Petein M, Abbeele AV (2008) Beta-tricalcium phosphate, white mineral trioxide aggregate, white Portland cement, ferric sulfate, and formocresol used as pulpotomy agents in primary pig teeth. Oral Surg Oral Med Oral Pathol Oral Radiol Endod 105(4): 536542 .

100. Fransson H, Wolf E, Petersson K (2016) Formation of a hard tissue barrier after experimental pulp capping or partial pulpotomy in humans: an updated systematic review. Int Endod J 49(6): 533-542.

101. Bergenholtz G, Axelsson S, Davidson T, Frisk F, Hakeberg M, et al. (2013) Treatment of pulps in teeth affected by deep caries - A systematic review of the literature. Singapore Dent J 34(1): 1-12.

102. Pimenta HC, Borges ÁH, Bandeca MC, Neves AT, Fontes RG, et al. (2015) Antimicrobial activity of filling materials used in primary teeth pulpotomy. J Int Oral Health 7(4): 54-57.

103. Camilleri J (2008) Characterization of hydration products of mineral trioxide aggregate. Int Endod J 41(5): 408-417.

104. Okiji T, Yoshiba K (2009) Reparative dentinogenesis induced by mineral trioxide aggregate: a review from the biological and physicochemical points of view. Int J Dent 2009: 464280.

105. Fridland M, Rosado R (2003) Mineral Trioxide aggregate (MTA) solubility and porosity with different water-to-powder ratios. J Endod 29(12): 814-817.

106. Torabinejad M, Hong C, Pitt Ford T, Kettering J (1995) Cytotoxicity of four root end filling materials. J Endod 21(10): 489-492.

107. Aeinehchi M, Eslami B, Ghanbariha M, Saffar A (2003) Mineral trioxide aggregate (MTA) and calcium hydroxide as pulp-capping agents in human teeth: A preliminary report. Int Endod J 36(3): 225231.

108. Maturo P, Costacurta M, Bartolino M, Docimo R (2009) MTA applications in pediatric dentistry. Oral Implantol 2(3): 37-44.

109. Witherspoon DE Vital pulp therapy with new materials: new directions and treatment perspectives-permanent teeth. J Endod 34(7 Suppl): S25-S28.

110. Eid AA, Komabayashi T, Watanabe E, Shiraishi T, Watanabe I (2012) Characterization of the mineral trioxide aggregate-resin modified glass ionomer cement interface in different setting conditions. J Endod 38(8): 1126-1129.

111. Cavalcanti BN, Rodesde M, França CM, Marques MM (2011) Pulp capping materials exert an effect on the secretion of IL-1 $\beta$ and IL- 8 by migrating human neutrophils. Braz Oral Res 25(1): 13-18.

112. Paranjpe A, Smoot T, Zhang H, Johnson JD (2011) Direct contact with mineral trioxide aggregate activates and differentiates human dental pulp cells. J Endod 37(12): 1691-1695.

113. Simon S, Perard M, Zanini M, Smith AJ, Charpentier E, et al. (2013) Should pulp chamber pulpotomy be seen as a permanent treatment? Some preliminary thoughts. Int Endod J 46(1): 79-87.

114. Azimi S, Fazlyab M, Sadri D, Saghiri MA, Khosravanifard B, et al. (2013) Comparison of pulp response to mineral trioxide aggregate and a bioceramic paste in partial pulpotomy of sound human premolars: a randomized controlled trial. Int Endod J 47(9): 873-881.

115. Barngkgei IH, Halboub ES, Alboni RS (2013) Pulpotomy of symptomatic permanent teeth with carious exposure using mineral trioxide aggregate. Iran Endod J 8(2): 65-68.

116. de Rysky S, Sapelli PL (1979) Vital amputation of the pulp with a new endodontic medication: histologic control of the pulpar stump. Riv Ital Stomatol 48(5): 5-12.

117. Frankl Z (1978) Treatment of vital exposed pulps in molars with N2 normal (II). Quintessence Int Dent Dig 9(5): 21-26. 
118. Hannah DR, Rowe AH (1971) Vital pulpotomy of deciduous molars using N2 and other materials. Br Dent J 130(3): 99-107.

This work is licensed under Creative Commons Attribution 4.0 License
119. Torabinejad M, Hong CU, McDonald F, Pitt Ford T (1995) Physical and chemical properties of a new root-end filling material. J Endod 21(7): 349-353.

\section{Your next submission with Juniper Publishers} will reach you the below assets

- Quality Editorial service

- Swift Peer Review

- Reprints availability

- E-prints Service

- Manuscript Podcast for convenient understanding

- Global attainment for your research

- Manuscript accessibility in different formats

( Pdf, E-pub, Full Text, Audio)

- Unceasing customer service

Track the below URL for one-step submission https://juniperpublishers.com/online-submission.php 